\title{
ANALISA GEAR RATIO MESIN CHANGE GEARBOX G2-1 TEIJIN JAPAN TERHADAP PROSES PRODUKSI PEMINTALAN SERAT POLYESTER SHORT CUT FIBER DI PT. TIFICO FIBER INDONESIA, TBK
}

\author{
$\operatorname{AMIR}^{(1)} \&$ KUSNADI ${ }^{(2)}$ \\ Program Studi Teknik Mesin, Fakultas Teknik, Universitas Muhammadiyah Tangerang \\ Jl. Perintis Kemerdekaan I/33 Cikokol-Tangerang \\ Email ${ }^{(1)}$ amirduta815@gmail.com
}

\begin{abstract}
Abstrak
Pada mesin change gearbox G2-1 Teijin japan sebagai salah satu mesin produksi secara berlanjut yang mana berfungsi untuk mengatur kecepatan pada ratio yang ditentukan sesusi produk yang digunakan, sering terjadi abnormal pada produk fiber yang digunakan, sehingga penulis perlu melakukan proses analisa perhitungan dan perbandingan tiga ratio pada mesin change gearbox supaya produk serat polyester ini bisa menjadi produk unggulan didalam maupun diluar negri. Hasil penelitian analisa perbandingan tiga ratio pada mesin change gearbox ini dari proses menghitung gear ratio dari mulai gear pertama sampai gear ke tiga. Menghitung gear ratio ini bertujuan untuk menarik kecepatan pada tarikan benang supaya ketika mesin change gearbox ini berjalan ini berjalan bisa menghasilkan produk yang sesuai standar. Untuk pengecekan serat polyester over length ( panjang abnormal ), oil pick up ( kandungan oil pada serat ) elongation ( kemuluran serat ) dan untuk pengecekan atau perawatan pada mesin change gearbox G2-1 adalah pengecekan secara rutin diantaranya pengecekan vibration, pengecekan temperatur, pengecekan strobo pada putaran mesin. Adapun beberapa permasalahan yang sering terjadi abnormal pada serat polyester short cut fiber diantaranya yaitu potongan fiber yang tidak sesuai, sering terjadinya banyak fiber yang terputus, dan kandungan oil pick up yang tinggi.
\end{abstract}

Kata kunci : Perbandingan, Gear ratio, Change gearbox, Short cut fiber, Abnormal.

\section{Pendahuluan}

Perusahaaan harus selalu melakukan peningkatan secara bertahap dan berkelanjutan disetiap departemen agar mampu bersaing dalam era globalisasi. Dalam hal ini departemen produksi memegang peranan penting untuk meningkatkan produksi pada perusahaan. Departemen produksi terdapat berbagai hal yang harus selalu ditingkatkan produktivitasnya, termasuk peralatan dan mesin yang mendukung proses produksi. Usaha perbaikan dalam dunia manufaktur, dari segi permesinan adalah dengan mengelola manajemen menghitung perbandingan gear ratio pada mesin change gearbox G2-1

Mengingat dalam dunia industri kegiatan produksi tidak lepas dari penggunaan alat - alat atau mesin mesin sebagai pendukung operasionalnya. Mesin change gearbox ini beroperasi sesuai dengan semestinya bila didukung oleh standar operasional dan perawatan yang benar. Seringkali produk serat polyester mengalami banyak masalah, mulai dari benang sering putus, benang keras, potongan tidak rata dan penarikan fiber yang kurang kencang maupun tingginya pada penarikan fiber sampai Pada akhirnya banyak kerugian yang terjadi yaitu waktu, cacat produk, biaya, dan masalah lainnya.

Dalam penelitian yang saya lakukan ialah menganalisa mesin change gearbox G2-1, cara kerja mesin change gearbox G2-1 ini yaitu merupakan suatu elemen mesin yang sebagai media untuk merubah kecepatan atau mengurangi putaran mesin sesuai yang diinginkan. Disamping juga mesin change gearbox ini untuk menyalurkan tenaga atau daya mesin ke salah satu bagian mesin lainnya, sehingga unit tersebut dapat bergerak menghasilkan sebuah pergerakan baik putaran maupun pergeseran. Untuk mesin change gearbox G2-1 ini sangat berpengaruh dalam proses penarikan fiber, yang mana fiber di tarik dengan kecepatan atau putaran yang kita inginkan. Seringkali fiber polyester ini mengalami masalah diantaranya benang sering putus dan potongan benang yang tidak sesuai standard perusahaaan itu di sebabkan karena ratio mesin change gearbox dan penarikan tegangan benang yg tidak pas sehingga mengakibatkan abnormal pada proses produksi. Maka dari itu kami penulis 
menganalisa gear ratio mesin change gearbox G2-1 Dengan tujuan supaya proses bisa berjalanan dengan lancar. Perbandingan gear ratio ini usaha yang dilakukan secara sengaja dan sistematis terhadap peralatan hingga merupakan suatu elemen mesin yang sebagai media untuk merubah kecepatan putaran mesin sesuai yang diinginkan. Dari pengertian diatas telah jelas bahwa kegiatan perbandingan gear ratio ini adalah kegiatan yang terprogram mengikuti cara tertentu untuk mendapatkan hasil atau kondisi yang disepakati. Perubahan gear ini hendaknya merupakan usaha atau kegiatan untuk mengurangi mesin abnormal ataupun pada proses produksi.

\subsection{Pengertian Mesin Change gearbox}

Mesin change gearbox adalah salah satu komponen utama motor yang disebut sebagai sistem pemindah tenaga, transmisi berfungsi untuk memindahkan dan mengubah tenaga motor yang berputar yang digunakan untuk memutar spindle mesin. Transmisi juga berfungsi untuk mengatur kecepatan gerak dan torsi, sehingga dapat bergerak kesamping. Transmisi manual atau lebih dikenal dengan sebutan gearbox mempunyai beberapa fungsi antara lain:

a. Merubah momen puntir yang akan diteruskan ke spindle mesin

b. Menyediakan ratio gigi yang sesuai dengan beban mesin.

c. Menghasilkan putaran mesin tanpa selip.

\subsection{Bagian - bagian mesin change gearbox} a. Spur Gear

Didalam mesin change gearbox ini ada yang namanya spur gear. Spur gear ada 3 posisi roda gigi yang mempunyai jumlah gigi yang berbeda - beda. Untuk gigi yang pertama berjumlah $78 \mathrm{~T}$, untuk jumlah roda gigi yang kedua berjumlah $72 \mathrm{~T}$, dan untuk jumlah roda gigi yang ketiga berjumlah $69 \mathrm{~T}$. Spur gear ini secara teratur digunakan pengurangan kecepatan atau meningkat peningkatan torsi perkalian, resolusi dan akurasi untuk posisi sistem. Gigi sejajar dengan sumbu gigi dan hanya dapat mentransfer gerak antara set gigi parallel sumbu.

b. Idle gear

Didalam mesin change gearbox ini ada yang namanya idle gear. Idle gear ini ada 4 posisi roda gigi yang mempuyai jumlah gigi yang berbeda - beda. Untuk gigi yang pertama berjumlah $52 \mathrm{~T}$, untuk jumlah roda gigi yang kedua $52 \mathrm{~T}$, untuk jumlah roda gigi yang ketiga berjumlah 52T, Dan untuk jumlah roda gigi yang ke empat berjumlah $54 \mathrm{~T}$. Idle gear ini secara teratur digunakan pengurangan kecepatan dan meningkat peningkatan torsi perkalian, resolusi dan akurasi untuk posisi sistem.

\section{c. Splin Gear}

Didalam mesin change gearbox ini ada yang namanya splin gear. Splin gear ini hanya memiliki satu gear saja yang berjumlah 65 T. Splin gear ini secara teratur untuk mengurangi maupun menpercepat putaran sesuai yang ditentukan.

\subsection{Macam - macam type produk serat polyester a. Short Cut}

Tipe serat polyester short cut ini adalah serat polyester yang mempunyai potongan sample yang pendek, yang digunakan sebagai pengganti serat kayu dalam pembuatan kertas contohnya seperti kertas filter, contoh tipe serat polyester tipe short cut yaitu SCF SD1.7 x 5P, yang artinya $1,7 \mathrm{~mm}$ untuk ketebalan seratya, dan $5 \mathrm{~mm}$ untuk panjang seratnya. b. Tipe Produk Reguler

Tipe serat polyester reguler ini yaitu serat yang digunakan untuk membuat produk benang dan di proses kembali untuk dijadikan bahan kain. Contoh Tipe serat polyester regular yaitu SD1,3 x 38 yang artinya 1,3 mm untuk ketebalan serat ( denier) dan $38 \mathrm{~mm}$ untuk panjang potongan seratnya.

\section{c. Hollow ( Fiber Fill )}

Tipe serat polyester hollow ini yaitu serat polyester yang digunakan untuk bahan pengisian ( dakron ) pada boneka dan bantal. Contoh tipe serat polyester hollow ini yaitu SD7 x 32 yang artinya 7 $\mathrm{mm}$ ketebalan serat dan $32 \mathrm{~mm}$ untuk panjang potongan seratnya.

\subsection{Macam - macam mesin change gearbox}

a. Change Gearbox Dengan Menggunakan Roda Gigi Miring

Poros yang terdapat pada change gearbox yang menggunakan roda gigi miring membentuk roda gigi miring membentuk sejajar satu dengan yang lainnya, poros input lebih kecil dibandingkan poros output.

b. Change Gearbox Dengan Menggunakan Roda Gigi

Lurus

Poros yang terdapat pada change gearbox yang menggunakan roda gigi lurus sama dengan roda gigi yang terdapat pada roda gigi miring yaitu membentuk sejajar satu dengan yang lainnya, poros input lebih kecil dibandingkan poros output.

c. Change Gearbox Dengan Menggunakan Roda Gigi Miring dan Roda Gigi Kerucut

Umumnya poros yang terdapat pada change gearbox yang menggunakan roda gigi miring dan roda gigi kerucut hampir sama dengan gearbox 
dengan menggunakan roda gigi cacing yaitu membentuk sudut $90^{\circ}$ satu dengan yang lainnya, poros output biasanya lebih besar dibandingkan dengan poros output.

\section{METODOLOGI PENELITIAN}

\subsection{Diagram alir ( flowchart )}

Penelitian dalam tugas ini meliputi: menentukan tujuan perbandingan rasio pada mesin change gearbox, reducer gear, gearbox dan tegangan tarik, mengumpulkan landasan teori untuk perbandingan, menentukan prosedur perbandingan ratio, melakukan perbandingan ratio dan analisa hasil perbandingan. Tahap - tahap tersebut disusun agar perbandingan ratio ini dapat berjalan secara sistematis, tahapan penelitian kemudian disusun dalam sebuah flowchart. Berikut ini adalah diagram alir (Flowchart) tentang penelitian "Analisa Gear Rati申 Mesigechange Gearbox G2-1 Terhadap Proses Pempntalan Ig Slg Polyester Short Cut Fiber":

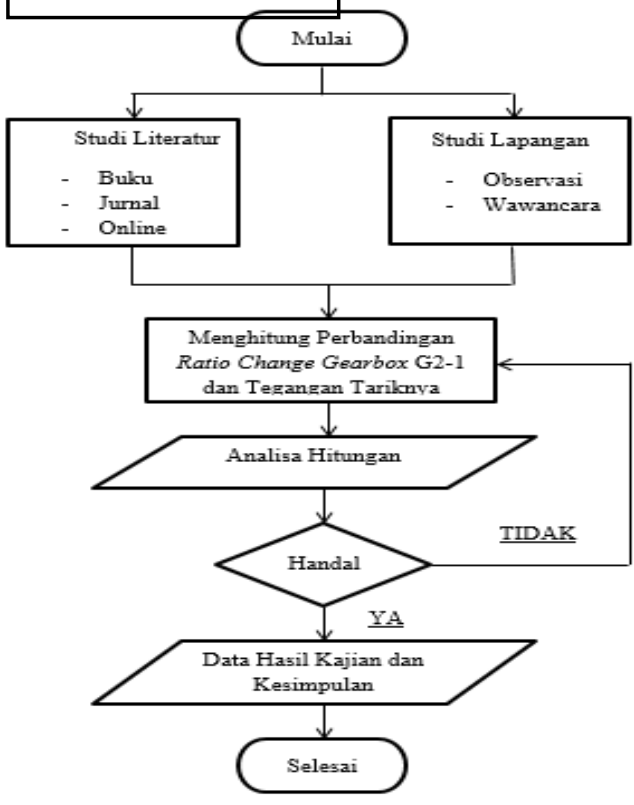

Gambar 2.1 Flowchart Penelitian

\subsection{Rumus perhitungan gear ratio}

Gear ratio yang dihitung pada penelitian ini yaitu

\begin{tabular}{|c|c|c|c|c|c|}
\hline $\begin{array}{c}\text { Nama } \\
\text { roda } \\
\text { gigi }\end{array}$ & $\begin{array}{l}\text { Jumlah } \\
\text { roda gigi } \\
\text { dan } \\
\text { Diameter } \\
\text { roda gigi }\end{array}$ & $\begin{array}{c}\text { Nama } \\
\text { roda } \\
\text { gigi }\end{array}$ & $\begin{array}{c}\text { Jumlah } \\
\text { roda gigi } \\
\text { dan } \\
\text { Diameter } \\
\text { roda gigi }\end{array}$ & $\begin{array}{c}\text { Nama } \\
\text { roda } \\
\text { gigi }\end{array}$ & $\begin{array}{c}\text { Jumlah } \\
\text { roda gigi } \\
\text { dan } \\
\text { Diameter } \\
\text { roda gigi }\end{array}$ \\
\hline $\begin{array}{l}\text { Spur } \\
\text { gear }\end{array}$ & $\begin{array}{c}69 \mathrm{~T} \\
(\times 50 \mathrm{~m})\end{array}$ & $\begin{array}{l}\text { Idle } \\
\text { gear }\end{array}$ & $\begin{array}{c}54 \mathrm{~T} \\
(\times 25 \mathrm{~m})\end{array}$ & \multirow[t]{4}{*}{$\begin{array}{l}\text { Splin } \\
\text { gear }\end{array}$} & \multirow[t]{4}{*}{$\begin{array}{c}65 \mathrm{~T} \\
(\propto 50 \mathrm{~m})\end{array}$} \\
\hline $\begin{array}{l}\text { Spur } \\
\text { gear }\end{array}$ & $\begin{array}{c}72 \mathrm{~T} \\
(\propto 50 \mathrm{~m})\end{array}$ & $\begin{array}{l}\text { Idle } \\
\text { gear }\end{array}$ & $\begin{array}{c}52 \mathrm{~T} \\
(\mathrm{Q} 25 \mathrm{~m})\end{array}$ & & \\
\hline \multirow[t]{2}{*}{$\begin{array}{l}\text { Spur } \\
\text { gear }\end{array}$} & \multirow[t]{2}{*}{$\begin{array}{c}78 \mathrm{~T} \\
(Q 50 \mathrm{~m})\end{array}$} & $\begin{array}{l}\text { Idle } \\
\text { gear }\end{array}$ & $\begin{array}{c}52 \mathrm{~T} \\
(\mathrm{Q} 25 \mathrm{~m})\end{array}$ & & \\
\hline & & $\begin{array}{l}\text { Idle } \\
\text { gear }\end{array}$ & $\begin{array}{c}52 \mathrm{~T} \\
(\propto 25 \mathrm{~m})\end{array}$ & & \\
\hline
\end{tabular}

gear ratio mesin change gearbox G2-1. Rumus perhitungan gear ratio pada mesin change gearbox G2-1 adalah sebagai berikut:

Keterangan :

$\mathrm{Sg}=$ Spur Gear

Ig = Idle Gear

Slg $=$ Splin Gear

\subsection{Rumus tegangan tarik}

Dengan menghitung gear ratio maka mempengaruhi dalam proses produksi pemintalan serat polyester yaitu mempengaruhi terhadap tegangan tariknya yang menyebabklan berpengaruhnnya pada kualitas sample tersebut, berupa kualitas kemuluran dan potongan fiber. Cara menghitung tegangan tarik pada proses pemintalan serat polyester yaitu besar gaya tarik dibagi dengan luas penampang suatu benda. Tegangan tarik termasuk gaya persatuan luas.

$$
\mathrm{OH}=\mathrm{F} / \mathrm{A}
$$

$$
\begin{aligned}
& \mathrm{O} \mathrm{t}=\text { Tegangan tarik }\left(\mathrm{kg} / \mathrm{cm}^{2}\right) \\
& \mathrm{F}=\text { Gaya yang bekerja } \\
& \mathrm{A}=\text { Luas penampang }
\end{aligned}
$$

\section{HASIL DAN PEMBAHASAN}

\subsection{Perbandingan gear ratio pada mesin change gearbox}

a. Ratio dan Rpm Mesin Change Gearbox

Tabel 3.1 Tegangan tarik

\begin{tabular}{|c|c|l|l|l|l|c|}
\hline $\begin{array}{c}\mathrm{N} \\
\mathrm{o}\end{array}$ & $\begin{array}{c}(\mathrm{n}) \\
\mathrm{rpm} \\
\text { motor }\end{array}$ & $\begin{array}{l}\text { Beban } \\
\text { danstr } \\
\text { ol ( } \\
\mathrm{kg})\end{array}$ & $\begin{array}{l}\text { Beban } \\
\text { chilinder } \\
\mathrm{kg})\end{array}$ & $\begin{array}{l}\text { Ratio c. } \\
\text { gearbox } \\
\mathrm{G} 2-1\end{array}$ & $\begin{array}{l}\text { Ratio } \\
\text { reduce } \\
\text { r gear }\end{array}$ & $\begin{array}{c}\text { Ratio } \\
\text { gearbo } \\
\mathrm{x}\end{array}$ \\
\hline 1 & 2000 & $4,0 \mathrm{~kg}$ & $1 \mathrm{~kg}$ & 1063 & $1: 4,8$ & $\begin{array}{c}0,490 \\
7\end{array}$ \\
\hline
\end{tabular}




\begin{tabular}{|c|c|c|c|c|c|c|}
\hline No & $\begin{array}{c}\mathrm{N} \\
(\mathrm{rpm})\end{array}$ & \multicolumn{2}{|c|}{$\begin{array}{l}\text { Output } N \\
\text { (reducer) }\end{array}$} & $\begin{array}{l}\text { Output } N \\
\text { (gearbox) }\end{array}$ & $\begin{array}{c}\text { Torsi } \\
\text { pada } \\
\text { mesin } \\
\text { change } \\
\text { gearbox }\end{array}$ & $\begin{array}{l}\text { Ratio } \\
\text { pada } \\
\text { mesin } \\
\text { change } \\
\text { gearbox }\end{array}$ \\
\hline 1 & 2000 & & 6 & 153.712 & 3207 & 1069 \\
\hline 2 & 2000 & & 6 & 153,712 & 3294 & 1098 \\
\hline 3 & 2000 & & 6 & 153,712 & 3600 & 1200 \\
\hline & \begin{tabular}{l|l}
2 &
\end{tabular} & 2000 & $6,0 \mathrm{~kg}$ & $2 \mathrm{~kg}$ & 1104 & $1: 4,8$ \\
\hline & 3 & 2000 & $8,0 \mathrm{~kg}$ & $3 \mathrm{~kg}$ & 1207 & $1: 4,8$ \\
\hline
\end{tabular}

Data tabel diatas adalah yang dipakai dalam penelitian tentang tegangan tarik ini sudah dalam bentuk hasil tanpa perhitungan rumus diatas, yang bersumber dari observasi dilapangan ( perusahaan tempat penelitian ) .

TFC21 - M-DZ-001 (Drawing document)

41045 ( Nomor seri )

35-1.023c2 ( Type document)

b. Jumlah Roda Gigi Mesin Change Gearbox

Jumlah roda gigi mesin change gearbox mulai dari roda gigi spur gear, idle gear dan splin gear dapat dilihat pada tabel dibawah ini:

Tabel 3.2 Jumlah dan diameter roda gigi pada change gearbox

Pada mesin change gearbox memiliki tiga pemindah gigi, dimana pemindah ini berfungsi untuk mempercepat dan mengurangi kecepatan sesuai produk yang digunakan, dan setiap produk memiliki ratio yang berbeda - beda. Dibawah ini berikut jumlah ratio pada tabel diatas :

- Untuk ratio pertama pemindah roda gigi pertama) ( $69 \mathrm{SG}: 54 \mathrm{ID})$ x $(54 \mathrm{ID}: 65 \mathrm{SPL})=1,24$ x 0,83 $=1.063$

Dibulatkan dalam tabel yang terdekat $=1.069$

- Untuk ratio kedua ( pemindah roda gigi kedua ) $(72 \mathrm{SG}: 52 \mathrm{ID}) \times(54 \mathrm{ID}: 65 \mathrm{SPL})=1.38 \times 0,8$ $=1.104$

Dibulatkan pada tabel yang terdekat $=1.098$

- Untuk ratio ketiga ( pemindah roda gigi ketiga )

( $78 \mathrm{SG}: 52 \mathrm{ID}$ ) $x(52 \mathrm{ID}: 65 \mathrm{SPL})=1,5 \times 0,8$ $=1,2$

Dibulatkan dalam tabel yang terdekat $=1.207$

\subsection{Perhitungan torsi}

Sebuah besaran yang menyatakan besarnya gaya yang bekerja pada sebuah benda sehingga mengakibatkan benda tersebut berotasi. Berikut adalah rumus untuk menghitung besarnya torsi pada roda gigi :

$$
\mathbf{T}=\mathbf{F} \times \mathbf{r}
$$

(Sumber:https://id.m.wikibooks.org)

Keterangan :

$\mathrm{T}=$ Torsi $($ Newton meter $)(\mathrm{NM})$

$\mathrm{F}=$ Gaya ( Newton $)(\mathrm{N})$

$\mathrm{r}=$ Jumlah roda gigi yang saling bersentuhan

Tabel 3.3 Perhitungan Torsi

Data tabel diatas adalah yang dipakai dalam

,49penelitian tentang tegangan tarik ini sudah dalam 7 bentuk hasil tanpa perhitungan rumus diatas, yang 7 bersumber dari observasi dilapangan ( perusahaan tempat penelitian ) .

TFC21 - M-DZ-001 (Drawing document)

41045 ( Nomor seri )

35-1.023c2 ( Type document)

\subsection{ANALISA}

\section{a. Analisa proses gear ratio dengan tegangan tarik}

Dalam mesin change gearbox ini memiliki 3 roda gigi untuk mengatur kecepatan putaran ratio yg pas digunakan untuk tipe short cut fiber. Dalam hal ini penulis menganalisa pada setiap ratio dari mesin change gearbox dengan tegangan tarik yang bertujuan untuk mengetahui berapa ratio yang digunakan pada mesin change gearbox dan berapa tegangan tarik yang bisa digunakan untuk tipe produk short cut fiber agar mencapai efisiensi dan produktifitas yang maksimal yang sesuai dengan standar, dalam pengujian perhitungan ratio dan tegangan tarik ini beberapa kali melakukan pengujian mulai dari gear ratio pertama sampai gear ratio ketiga dengan tipe short cut fiber. Di bawah ini adalah tabel perhitungan analisa 3 ratio mesin change gearbox dengan tegangan tarik yang dilakukan dengan dua pengujian.

\section{b. Pengujian 1}

Perhitungan perbandingan ratio mesin change gearbox dengan tegangan tarik pada pengujian pertama untuk mengetahui efisiensi dan produktifitas yang maksimal pada produk short cut fiber adalah seperti dibawah ini :

Tabel 3. 4 Perbandingan ratio dan tegangan tarik pada uji ke-1

\begin{tabular}{|c|c|c|c|}
\hline \multirow{2}{*}{ No } & \multirow{2}{*}{$\begin{array}{c}\text { Ratio } \\
\text { change } \\
\text { gearbox }\end{array}$} & $\begin{array}{c}\text { Tegangan tarik } \\
\text { danstrol } \\
(\mathrm{kg})\end{array}$ & $\begin{array}{c}\text { Beban } \\
\text { silinder } \\
(\mathrm{kg})\end{array}$ \\
\hline 1 & 1069 & 4,0 & 1,0 \\
\hline 2 & 1098 & 6,0 & 2,0 \\
\hline 3 & 1207 & 8,0 & 3,0 \\
\hline
\end{tabular}


- Untuk pengujian pertama menggunakan ratio 1069 dengan tegangan tarik beban danstrol $4.0 \mathrm{~kg}$ dan beban silinder $1,0 \mathrm{~kg}$, setelah dalam proses berjalan ratio dan tegangan tarik ini bermasalah atau tidak singkron, dimana permasalahannya adalah tarikan yang masih terlalu kencang sehingga menyebabkan terjadinya fiber dengan tegangan tarik yg terlalu kencang sehingga menimbulkan fiber short cut ini yang terputus.

2.126,00 rpm mesin change gearbox $\mathrm{X}$ 1069 , Ratio $=2.272 .694: 5,0 \mathrm{~kg}=$ $454.538,8 \mathrm{~m} / \mathrm{menit}$

- Untuk pengujian kedua menggunakan ratio 1098 dengan tegangan tarik beban danstrol $6,0 \mathrm{~kg}$ dan beban silinder $2,0 \mathrm{~kg}$, setelah dalam proses berjalan ratio dan tegangan tarik tidak bermasalah atau fiber short cut dalam kondisi normal.

2.208,00 rpm mesin change gearbox $\mathrm{X}$ 1098 Ratio $=2.424 .384: 8,0 \mathrm{~kg}=$ $303.048 \mathrm{~m} / \mathrm{menit}$

- Untuk pengujian ketiga menggunakan ratio 1207 dengan tegangan tarik beban danstrol $8,0 \mathrm{~kg}$ dan beban silinder $3,0 \mathrm{~kg}$, setelah dalam proses berjalan ratio dan tegangan tarik bermasalah atau tidak singkron, dimana permasalahannya adalah tarikan yang masih kendor sehingga menyebabkan terjadinya fiber dengan tegangan tarik yang terlalu kendor, dan menimbulkan fiber short cut potongan yang tidak sesuai.

2.400,00 rpm mesin change gearbox $\mathrm{X}$ 1207 Ratio $=2.896 .800: 11,0 \mathrm{~kg}=$ $263.345,45 \mathrm{~m} /$ menit.

\section{c. Pengujian 2}

Perhitungan ratio mesin change gearbox dengan tegangan tarik pada pengujian yang kedua untuk mengetahui efisiensi dan produktifitas yang maksimal pada produk short cut fiber adalah sebagai berikut :

Tabel 3.5 Perbandingan ratio dan tegangan tarik pada uji ke-2

\begin{tabular}{|c|c|c|c|}
\hline \multirow{2}{*}{ No } & \multirow{2}{*}{$\begin{array}{c}\text { Ratio } \\
\text { change } \\
\text { gearbox }\end{array}$} & $\begin{array}{c}\text { Teban } \\
\text { danstrol } \\
(\mathrm{kg})\end{array}$ & $\begin{array}{c}\text { Tegangan tarik } \\
\text { Bilinder } \\
(\mathrm{kg})\end{array}$ \\
\hline 1 & 1069 & 3,5 & 0,5 \\
\hline 2 & 1098 & 6,0 & 2,0 \\
\hline 3 & 1207 & 8,5 & 3,5 \\
\hline
\end{tabular}

- Dalam pengujian 1 dengan ratio 1069 yang masih ada masalah, penulis menganalisa dengan pengujian yang ke 2 yaitu dengan perubahan menurunkan tegangan tarik dengan beban danstrol 3,5 $\mathrm{kg}$ dan beban silinder $0,5 \mathrm{~kg}$, setelah dalam proses berjalan ratio dan tegangan tarik menjadi normal atau tidak ada masalah atau tipe short cut fiber dalam kondisi normal tetapi hasil fiber yang dihasilkan lebih bertambah dibandingkan dengan hasil tes yang pertama.

2.126,00 rpm mesin change gearbox $\mathrm{X} 1069$ Ratio $=2.272 .694: 4,0=$ $568.173,5 \mathrm{~m} /$ menit.

- Dalam pengujian 2 dengan ratio 1098 tidak ada masalah ketika proses berjalan sehingga tidak ada perubahan dalam tegangan tarik atau masih sama dengan pengujian yang pertama.

2.208,00 rpm mesin change gearbox $\mathrm{X} 1098$ Ratio $=2.424 .384: 8,0 \mathrm{~kg}=$ $303.048 \mathrm{~m} / \mathrm{menit}$

- Dalam pengujian ketiga dengan ratio 1207 yang masih ada masalah, penulis menganalisa pengujian yang ke 2 yaitu dengan menaikan tegangan tarik dengan beban danstrol $8,5 \mathrm{~kg}$ dan beban silinder 3,5 setelah dalam proses berjalan ratio dan tegangan tarik menjadi normal atau tidak ada masalah pada tipe short cut fiber dalam kondisi normal tetapi hasil fiber yang dihasilkan lebih berkurang dibandingkan dengan hasil tes yang pertama.

$$
\begin{aligned}
& \text { 2.400,00 rpm mesin change } \\
& \text { gearbox X } 1207 \text { Ratio }=2.896 .800 \text { : } \\
& 12,0 \mathrm{~kg}=241.400 \mathrm{~m} / \mathrm{menit}
\end{aligned}
$$

\subsection{Hasil Pengujian}

Dari data dua pengujian diatas, maka didapatkan data sebagai berikut:

a. Untuk tegangan tarik pada ratio 1069

Tabel 3.6 Produksi short cut fiber dengan ratio 1069

\begin{tabular}{|c|c|}
\hline Ratio 1069 & $\begin{array}{c}\text { Produksi Short Cut } \\
\text { Fiber dalam } \\
\mathrm{m} / \mathrm{menit}\end{array}$ \\
\hline $\begin{array}{c}\text { Dengan tegangan } \\
\text { tarik 5 kg (uji ke-1) }\end{array}$ & $454.538,8$ \\
\hline $\begin{array}{c}\text { Dengan tegangan } \\
\text { tarik 4 kg (uji ke-2) }\end{array}$ & $568.173,5$ \\
\hline
\end{tabular}


Dari data tabel 4.3 diatas dapat diliat bahwa untuk ratio 1069 pada uji ke-1 dengan menggunakan tegangan tarik $5 \mathrm{~kg}$ yang merupakan beban danstrol 4 $\mathrm{kg}$ ditambah dengan beban silinder $1 \mathrm{~kg}$ akan mendapatkan hasil produksi short cut fiber sebanyak $454.538,8 \mathrm{~m} / \mathrm{menit}$, sedangkan untuk ratio 1069 pada uji ke-2 dengan menggunakan tegangan tarik $4 \mathrm{~kg}$ yang merupakan beban danstrol $3,5 \mathrm{~kg}$ ditambah dengan beban silinder $0,5 \mathrm{~kg}$ akan mendapatkan hasil produksi short cut fiber sebanyak 568.173,5 m/menit. Jadi pada uji ke-1 dan uji ke-2 didapatkan selisih hasil produksi sebanyak $113.634,7 \mathrm{~m} /$ menit lebih banyak dengan uji ke-2 dibandingkan dengan uji ke-1.

Berikut adalah grafik perbandingan produktifitas dengan perbedaan tegangan tarik pada ratio change gearbox 1069 :

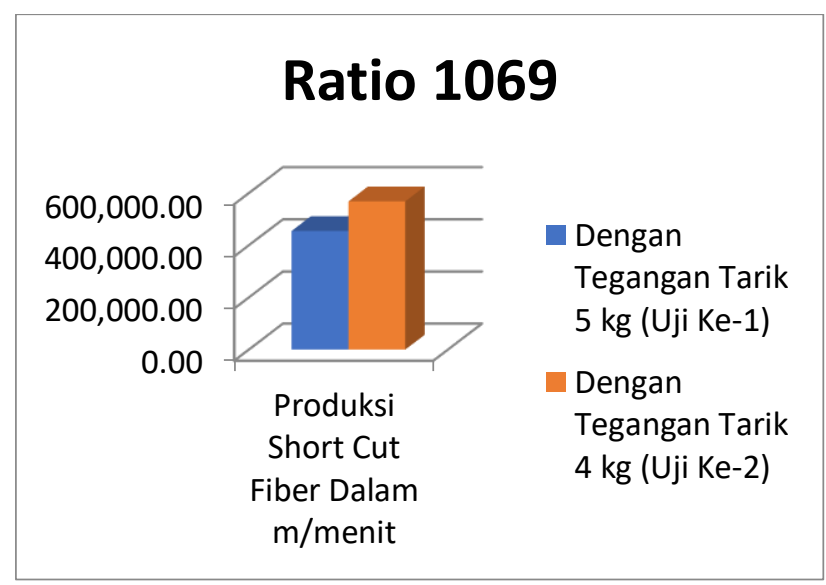

\section{Gambar 3.1 Perbandingan ratio 1069} dengan tegangan tarik

Dari data grafik diatas dilihat bahwa ratio 1069 dengan tegangan $5 \mathrm{~kg}$ ( beban danstrol $4 \mathrm{~kg}+$ beban silinder $1 \mathrm{~kg}$ ) produksi short cut fibernya lebih sedikit dibandingkan dengan ratio 1069 dengan tegangan tarik $4 \mathrm{~kg}$ (beban danstrol 3,5 kg + beban silinder 0,5). Itu dikarenakan dengan menggunakan tegangan tarik $5 \mathrm{~kg}$, maka tegangan tarik produk lebih besar yang mengakibatkan terjadinya benang putus lebih banyak sehingga menjadikan produksi short cutnya lebih sedikit dibandingkan yang menggunakan tegangan tarik $4 \mathrm{~kg}$. Dengan demikian pada ratio change gearbox 1069 jika ingin lebih efisien dan untuk meningkatkan produksi maka digunakan tegangan tarik $4 \mathrm{~kg}$ yang merupakan beban danstrol sebesar 3,5 $\mathrm{kg}$ dan beban silinder sebesar $0,5 \mathrm{~kg}$.

b. Untuk tegangan tarik pada ratio 1098

Tabel 3.7 Produksi short cut fiber dengan ratio 1098

\begin{tabular}{|c|c|}
\hline Ratio 1098 & $\begin{array}{c}\text { Produksi Short Cut } \\
\text { Fiber dalam } \\
\text { m/menit }\end{array}$ \\
\hline $\begin{array}{c}\text { Dengan tegangan tarik } \\
\text { 8 kg (uji ke-1) }\end{array}$ & 303.048 \\
\hline $\begin{array}{c}\text { Dengan tegangan tarik } \\
\text { 8 kg (uji ke-2) }\end{array}$ & 303.048 \\
\hline
\end{tabular}

Dari data tabel 4.4 diatas dapat diliat bahwa untuk ratio 1098 pada uji ke-1 maupun uji ke-2 tidak ada perubahan pada tegangan tarik, dikarenakan tipe produk short cut dengan menggunakan ratio ini tidak ada masalah atau abnormal, sehingga pada uji ke-2 tidak ada perubahan dengan tegangan tariknya. Berikut adalah grafik perbandingan produktifitas dengan perbedaan tegangan tarik pada ratio change gearbox 1098 :

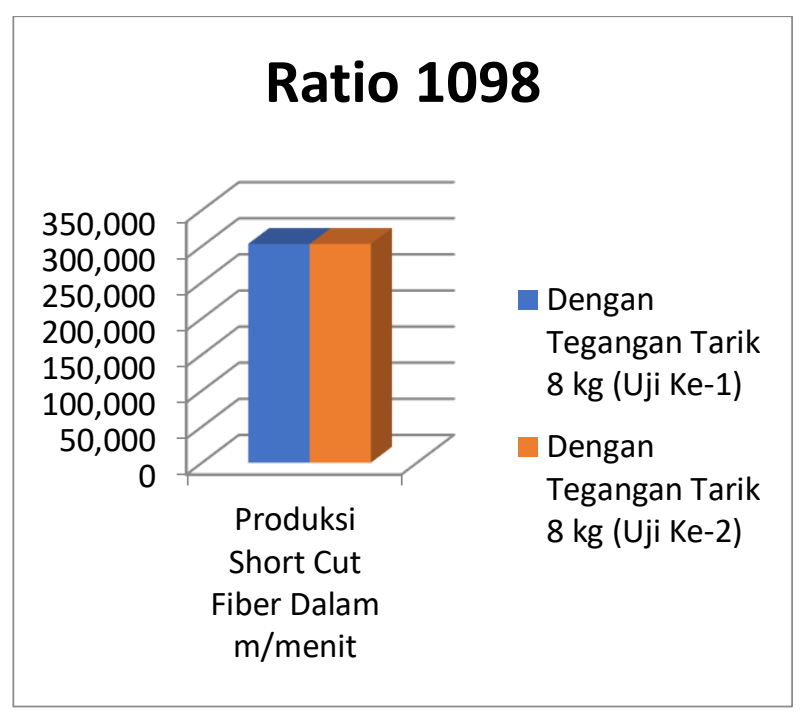

Gambar 3.2 Perbandingan ratio 1098 dengan tegangan tarik

Dari data grafik diatas dilihat bahwa ratio 1098 dengan tegangan $8 \mathrm{~kg}$ (beban danstrol $6 \mathrm{~kg}+$ beban silinder $2 \mathrm{~kg}$ ) pada uji pertama maupun kedua tidak ada perubahan, dikarenakan pada ratio 1098 tidak ada abnormal pada produk short cut fibernya.

c. Untuk tegangan tarik pada ratio 1207

Tabel 3.8 Produksi short cut fiber

dengan ratio 1207

\begin{tabular}{|c|c|}
\hline Ratio 1207 & $\begin{array}{c}\text { Produksi Short } \\
\text { Cut Fiber dalam } \\
\mathrm{m} / \text { menit }\end{array}$ \\
\hline $\begin{array}{c}\text { Dengan tegangan tarik } \\
11 \mathrm{~kg} \text { (uji ke-1) }\end{array}$ & $263.345,45$ \\
\hline $\begin{array}{c}\text { Dengan tegangan tarik } \\
12 \mathrm{~kg} \text { (uji ke-2) }\end{array}$ & 241.400 \\
\hline
\end{tabular}


Dari data tabel 4.3 diatas dapat diliat bahwa untuk ratio 1207 pada uji ke-1 dengan menggunakan tegangan tarik $11 \mathrm{~kg}$ yang merupakan beban danstrol $8 \mathrm{~kg}$ ditambah dengan beban silinder $3 \mathrm{~kg}$ akan mendapatkan hasil produksi short cut fiber sebanyak $263.345,45 \mathrm{~m} / \mathrm{menit}$, sedangkan untuk ratio 1207 pada uji ke-2 dengan menggunakan tegangan tarik 12 $\mathrm{kg}$ yang merupakan beban danstrol 8,5 $\mathrm{kg}$ ditambah dengan beban silinder $3,5 \mathrm{~kg}$ akan mendapatkan hasil produksi short cut fiber sebanyak $241.400 \mathrm{~m} /$ menit. Jadi pada uji ke-1 dan uji ke-2 didapatkan selisih sebanyak 21.945,45 m/menit lebih banyak dengan uji ke-2 dibandingkan dengan uji ke-1.

Berikut adalah grafik perbandingan produktifitas dengan perbedaan tegangan tarik pada ratio change gearbox 1098 :

\section{Ratio 1207}

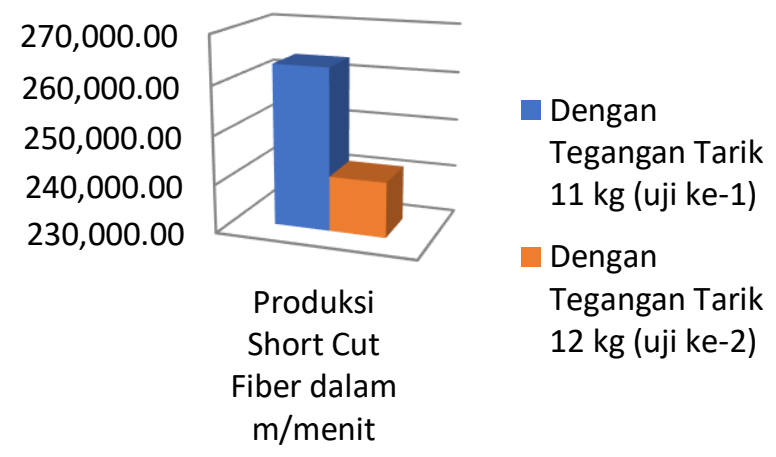

Gambar 3.4 Perbandingan ratio 1207

dengan tegangan tarik

Dari data grafik diatas dapat dilihat bahwa pada ratio 1207 dengan tegangan tarik $11 \mathrm{~kg}$, maka produksi short cut fibernya lebih meningkat jika dibandingkan dengan menggunakan tegangan tarik $12 \mathrm{~kg}$ pada uji ke-2. Namun walaupun produksinya lebih meningkat tetapi dengan tegangan tarik sebesar $11 \mathrm{~kg}$ pada ratio 1207 ini menyebabkan tarikan pada produk lebih kendor, yang berakibat pada banyaknya potongan yang tidak sesuai dengan standar, yang akhirnya menyebabkan produk menjadi abnormal. Jadi yang lebih sesuai dengan standar adalah dengan menggunakan tegangan tarik $11 \mathrm{~kg}$ pada uji ke-1. Dengan demikian pada ratio change gearbox 1207 jika ingin lebih efisien dan untuk meningkatkan produksi maka digunakan tegangan tarik $12 \mathrm{~kg}$ yang merupakan beban danstrol sebesar 8,5 kg dan beban silinder sebesar $3,5 \mathrm{~kg}$.

\section{Kesimpulan}

Dari hasil penelitian yang dilakukan dapat disimpulkan bahwa :

1. Gear ratio pada change gearbox G2-1 mempunyai 3 roda gigi yang masing - masing mempunyai ratio yang berbeda, yaitu gear ratio 1069, gear ratio 1098, dan gear ratio 1207.

2. Untuk ratio 1069 pada uji ke-1 dengan menggunakan tegangan tarik $5 \mathrm{~kg}$ yang merupakan beban danstrol $4 \mathrm{~kg}$ ditambah dengan beban silinder $1 \mathrm{~kg}$ akan mendapatkan hasil produksi short cut fiber sebanyak 454.538,8 $\mathrm{m} /$ menit, sedangkan untuk ratio 1069 pada uji ke2 dengan menggunakan tegangan tarik $4 \mathrm{~kg}$ yang merupakan beban danstrol $3,5 \mathrm{~kg}$ ditambah dengan beban silinder $0,5 \mathrm{~kg}$ akan mendapatkan hasil produksi short cut fiber sebanyak 568.173,5 $\mathrm{m} /$ menit. Jadi pada uji ke-1 dan uji ke-2 didapatkan selisih hasil produksi sebanyak $113.634,7 \mathrm{~m} /$ menit lebih banyak dengan uji ke-2 dibandingkan dengan uji ke-1, dan tegangan tariknya lebih baik dibandingkan dengan uji ke-1 yang terlalu kencang dan mengakibatkan banyak fiber yang terputus.

3. Untuk ratio 1098 pada uji ke-1 maupun uji ke-2 tidak ada perubahan pada tegangan tarik, dikarenakan tipe produk short cut dengan menggunakan ratio ini tidak ada masalah atau abnormal, sehingga pada uji ke-2 tidak ada perubahan dengan tegangan tariknya.

4. Untuk ratio 1207 pada uji ke-1 dengan menggunakan tegangan tarik $11 \mathrm{~kg}$ yang merupakan beban danstrol $8 \mathrm{~kg}$ ditambah dengan beban silinder $3 \mathrm{~kg}$ akan mendapatkan hasil produksi short cut fiber sebanyak 263.345,45 $\mathrm{m} /$ menit, sedangkan untuk ratio 1207 pada uji ke2 dengan menggunakan tegangan tarik $12 \mathrm{~kg}$ yang merupakan beban danstrol 8,5 $\mathrm{kg}$ ditambah dengan beban silinder 3,5 kg akan mendapatkan hasil produksi short cut fiber sebanyak 241.400 $\mathrm{m} /$ menit. Jadi pada uji ke-1 dan uji ke-2 didapatkan selisih sebanyak $21.945,45 \mathrm{~m} /$ menit lebih banyak dengan uji ke-2 dibandingkan dengan uji ke-1.

5. Untuk ratio 1069 lebih baik menggunakan tegangan tarik dengan beban $4 \mathrm{~kg}$ pada uji ke-2 yang akan bisa meningkatkan hasil produksi short cut fiber dan meminimalisir abnormal. Untuk ratio 1098 tetap menggunakan tegangan tarik dengan beban $8 \mathrm{~kg}$ dikarenakan tidak adanya abnormal. Dan untuk ratio 1207 lebih baik menggunakan tegangan tarik dengan beban $12 \mathrm{~kg}$ pada uji ke-2 untuk meminimalisir masalah fiber kendor seperti uji ke-1 yang mengakibatkan 
banyak abnormal potongan yang tidak sesuai, dengan uji ke-2 maka akan didapatkan hasil produksi yang lebih baik dan tidak menimbulkan abnormal.

\section{Daftar Pustaka}

Agustinus Purna Irawan. 2016. "Perancangan Sistem Transmisi Roda Gigi”. Yogyakarta: Kanisius.

Ibrahim, Bustami, dkk. "Perancangan Gearbox Traktor Tangan 2 Kecepatan 1 Mundur Dengan Sistem Pemindah Gigi Synchromesh." JTM Volume 4 Nomor 1 Tahun 2018. ISSN 2502$2581 .$.

Igak Suriadi. "Perancangan Rasio Sistem Transmisi Kendaraan Penggerak Roda Belakang Untuk Meningkatkan Kinerja Traksi”. Jurnal Energi dan Manufaktur Volume 9 Nomor 1 Tahun 2016, 4448.

I Gusti Agung Kade Suriadi. "Perbaikan Performa Traksi dengan Modifikasi Rasio Gigi Transmisi". Jurnal Energi dan Manufaktur Volume 7 Nomor 2 Tahun 2014, 119-224.

Robert L. Mott. 2004. "Elemen-Elemen Mesin Dalam Perancangan Mekanis." Yogyakarta: Andi

Robert L. Mott. 2009. "Elemen-Elemen Mesin Dalam Perancangan Mesin Terpadu Buku 2 " Yogyakarta: Andi

Siregar, Syofian. 2011. "Statistik Deskriptif untuk Penelitian”. Jakarta: PT Raja Grafindo Persada.

Sri Mulyono. 2017. “Riset Operasi Edisi 2”. Jakarta: Mitra Wacana Media

Sularso, Kiyokatsu Suga. 2008. "Dasar Perencanaan dan Pemilihan Elemen Mesin”. Jakarta: Pradnya Paramita.

Tri Widodo Besar Riyadi, Purnomo. 2018. "Perhitungan Pada Perancangan Elemen Mesin". Surakarta: MUP 